\title{
LA EXPRESIÓN DEL ACUERDO Y EL DESACUERDO EN EL DISCURSO POLÍTICO: UN ANÁLISIS SOCIO-COGNITIVO
}

\author{
Isabel $M^{a}$ Íñigo Mora \\ Universidad de Sevilla
}

\begin{abstract}
The purpose of this paper is twofold: on the one hand to show that one specific linguistic form rarely conveys one single function because its interpretation highly depends on its concurring context, linguistic as well as social. On the other hand, to demonstrate convincingly that only when we take into consideration both social and cognitive factors we can reach a nonbiased conclusion.

In order to attain these two goals we have analysed one specific type of discourse: the political discourse. Specifically, the way members of parliament aim at reaching a certain amount of persuasion of one another in their presentation of the oral questions and answers (i.e. Question Time) at the House of Commons. It seems that one apparent linguistic behaviour connected to this social activity is the expression of agreement and disagreement and that is why it appeared to be a good subject of analysis. The first step was to select the sessions subject of analysis and I determined that they should embrace some thematic continuity; that is why I chose five sessions which dealt about one issue representing the most important governmental initiative in the education service of England and Wales since 1944: the 1988 Education Reform Act. The second step was to analyse all the questions and answered proffered in order to trace expressions to be interpreted as agreements or disagreements in the context. And finally, I have attempted to offer two different interpretations of the resalts, one taking into account only social factors and another considering both, social and cognitive parameters.
\end{abstract}

\section{INTRODUCCIÓN}

La gran mayoría de las investigaciones encaminadas a analizar las expresiones de acuerdo y desacuerdo lo han hecho partiendo de dos líneas fundamentales: por una parte aquella que se enmarca dentro de los estudios de pragmática de la cortesía, y por otra, la que se localiza dentro de los análisis de la conversación. Evidentemente, tanto una como otra recurre a explicaciones fundamentalmente sociales que sean capaces de interpretar determinados comportamientos lingüísticos. Como se podrá apreciar a lo largo de este trabajo, no siempre se alcanzan conclusiones satisfactorias si nos ceñimos a una de las funciones de la comunicación humana. El hombre responde a una serie de condicionantes cognitivos que determinan de forma crucial su comportamiento en la sociedad. Por tanto, la idea que aquí se defiende y se pretende demostrar es que tan sólo mostrando el comportamiento humano desde una perspectiva integral ${ }^{1}$ que observe todas sus dimensiones

\footnotetext{
${ }^{1}$ Para el concepto de integral, véase R. Harris y G. Wolf (1998).
} 
podremos alcanzar explicaciones de valor más objetivo y libre de cualquier sesgo prejuiciado por la teoría epistemológica de partida.

Para ello, se eligió un contexto en el que las expresiones pudieran de acuerdo y desacuerdo juegasen un papel primordial y que, sin lugar a dudas, pueden acarrear importantes repercusiones. Con estas características tan sólo podríamos estar hablando de un lugar: el parlamento. En concreto, la escena tomada fue la Cámara de los Comunes. Como es bien sabido, los políticos tienden a hacer uso de un lenguaje cargado de ingenio y agudeza, y es que ésta es la única arma permitida en la arena parlamentaria. Sin lugar a dudas, una de las actividades más comunes no es otra que intentar convencer al adversario para que diga o haga algo que beneficie a su grupo político. A pesar de que toda la actividad parlamentaria está llena de innumerables ejemplos de este tipo de comunicación (i.e. comunicación persuasiva) ${ }^{2}$, las denominadas Oral Answers to Questions llaman la atención por su viveza y espontaneidad. Aunque las preguntas a los representantes ministeriales tienen que ser presentadas por escrito a la Mesa con unos días de anticipación ${ }^{3}$, si algún diputado de la Cámara no queda satisfecho con la respuesta ofrecida, éste siempre podrá realizar una pregunta suplementaria. A partir de ese momento, todo es imprevisible y la audacia y el ingenio son los únicos recursos para vencer al adversario. Con el fin de conservar una coherencia temática y a la vez una continuidad cronológica, he seleccionado cinco sesiones parlamentarias que se centran en un problema concreto. Pensando en la discusión de un evento que hubiese sido capaz de centrar la atención de todos los ciudadanos británicos, decidí analizar cuatro sesiones previas y una posterior a la aprobación de la Ley de 1988 sobre la Reforma Educativa.

\section{LOS PROCESOS DE INTERPRETACIÓN Y COMPRENSIÓN DE LA REALIDAD}

Para entender los fenómenos comunicativos antes descritos, en primer lugar, habría que descubrir cómo funciona la mente humana con respecto a la comunicación. Las distintas teorías cognitivas están basadas en tres ideas fundamentales que según Escandell (1996: 634) son: (1) que la mente es un sistema simbólico al cual trasladamos nuestras percepciones físicas en forma de unas representaciones internas que finalmente constituirán nuestros "supuestos; (2) la percepción, el comportamiento y la comprensión dependerán de forma crucial de nuestros conocimientos previos; y (3) el conocimiento humano está estructurado de manera muy compleja, de tal forma que nuestras representaciones internas no son una simple lista (de elementos) sino que forman una red compleja de conjuntos de elementos organizados ${ }^{4}$.

Dependiendo del autor, esta estructura compleja del conocimiento humano será designada con distintos términos tales como frame (Hymes, 1974 y Minsky, 1975, 1986), schema (Rumelhart, 1975), script (Schank y Abelson, 1977) o scenario (Sanford y Garrot, 1981). Todos estos diferentes términos están basados en una idea central: que todo individuo organiza el conocimiento basándose en las experiencias que él mismo tiene del mundo, y que utiliza este conocimiento en el proceso de interpretación. Así, las ideas principales de un enunciado activan un determinado "esquema" y en consonancia y

\footnotetext{
${ }^{2}$ Este término ha sido tomado de E. Bettinghaus (1973:9).

${ }^{3} \mathrm{Y}$ por tanto, tener tiempo suficiente para preparar una respuesta perfectamente elaborada.

${ }^{4}$ Véase Sperber y Wilson (1995) Relevance.
} 
coherencia con éste genera una serie de inferencias fruto de esta asociación. Escandell (1996: 636) añade:

"In addition, specific knowledge provides us not only with a pattern for understanding, but also
with a pattern of behaviour. Since our mental representation of a particular situation should also
contain not only information on participants and activities, but also on the appropriate use of
language, we find that much of our (linguistic) behaviour is, therefore, determined by specific
knowledge."

También se deberán tener en cuenta las expectativas del individuo perceptor, que determinarán de manera singular la interpretación del mensaje. Tal y como indica Lillo (1993: 457):

"El procesamiento relacionado con el reconocimiento no depende sólo de la naturaleza de la estimulación que llega a la retina, sino también de las expectativas presentes en el sujeto perceptor. Estas, además de influir en la naturaleza del flujo informativo del que se dispone, pueden determinar la forma en que se interpreta."

Además, Dember y Warm (1990) insisten también en la importancia decisiva de las características del contexto de emisión. Así, estos autores señalan que: “. . . nuestra percepción de los estímulos suele estar determinada por el contexto en el que suceden. La dimensión de incertidumbre es un aspecto decisivo del marco contextual que influye en la actividad perceptiva." (Dember y Warm, 1990: 119)

Teniendo en cuenta todos estos factores, el individuo en su rol social de persuasor tratará de producir un enunciado tal que sea capaz de generar una respuesta específica en su receptor, en concreto, un cambio en su opinión, y/o percepción, y/o afecto, y/o acción. Pero tal y como afirma Bettinghaus (1973: 30) "Participants have to perceive before they can respond" y esto quiere decir que el receptor tendrá que recibir un determinado estímulo que desencadene todo el proceso de la persuasión. La función del estímulo es atraer la atención del receptor y centrar esta atención en las intenciones del emisor ${ }^{5}$, de tal forma que haga manifiesto o más manifiesto un conjunto de supuestos a su receptor.

Por otra parte, la proposición debe poseer información nueva, no totalmente conocida. Según Echeverría (1995: 75) "El receptor sólo puede cambiar su comportamiento ulterior o su actitud en la medida en que recibe del emisor algo diferente de lo que ya conoce, no una pura y simple repetición de los elementos que ya posee." Además, este carácter novedoso del mensaje, deberá estimular la capacidad creativa de su receptor; es decir, debe implicar movimiento: "Debe fomentar su propia creatividad, induciéndole a aceptar o establecer nuevas formas de comportamiento al tratar de incorporar las nuevas informaciones en sus esquemas preestablecidos." (Echeverría, 1995: 75). Esta novedad deberá producirse tanto en la forma como en el contenido, o lo que es lo mismo, en el "qué" decir y en el "cómo" contamos algo sea o no conocido. Pero debe aplicarse un principio general pragmático de relevancia (binomio de mínimo esfuerzo y máximo efecto contextual ${ }^{6}$ ) y esto conllevará utilizar formas simples:

\footnotetext{
${ }^{5}$ Estas son las dos condiciones que debe satisfacer un estímulo ostensivo (Sperber y Wilson, 1995: 153).
}

${ }^{6}$ Sperber y Wilson (1995) Relevance. 
"Lo que se busca en la transmisión de un mensaje es la percepción de éste con el menor esfuerzo posible por parte del receptor, así como la asimilación del significado que pretendemos y un cambio de actitud o de comportamiento." (1995: 77-8).

Echeverría explica que esta novedad dependerá, ante todo, del carácter inesperado del mensaje (tanto en forma como en contenido). Esta función especial del estímulo novedoso ha sido bastante analizada en diversos estudios experimentales realizados en el área de la psicología de la percepción. Desde esta área se sostiene que, para hacer frente a la gran cantidad de información que constantemente llega a nuestros sentidos, el ser humano no tiene más remedio que ser selectivo y procesar la más importante en detrimento de la menos importante. Rock (1985: 233) dice así:

"Nuestra mente impone una organización a la estimulación entrante, funciona según ciertas
reglas de preferencia y es particularmente sensible a las relaciones entre estímulos; infiere y
calcula; basa sus inferencias en ciertos "supuestos"; toma en cuenta un tipo de información
sensorial al valorar la importancia de la de otro tipo."

Ya en 1975 Luria distinguía dos grupos de factores determinantes de la atención: (1) los que caracterizan la estructura de los estímulos externos que llegan al individuo y (2) los relativos a la actividad del propio sujeto. A todo esto hay que añadir que, además, existen al menos dos factores constitutivos de los estímulos que el sujeto percibe desde el exterior que determinan el sentido de la atención: (i) la intensidad (fuerza) del estímulo; y (ii) la novedad del estímulo (o su diferencia con respecto a otros estímulos). El primero predice que: "Cuando el sujeto se halla ante un grupo de estímulos iguales o dispares, uno de los cuales se destaca por su intensidad (magnitud, color, etc...), su atención se-ve atraída cabalmente por ese estímulo" (Luria, 1987: 8) Y el segundo adelanta que: "Si entre estímulos bien conocidos aparece uno que se distingue radicalmente de los demás o es inusitado, nuevo, comienza a atraer enseguida la atención y suscita un especial reflejo de orientación." (Luria, 1987: 8). Existe, además, otro factor de los estímulos que el sujeto percibe desde el exterior y que determinará el volumen de la atención: la organización estructural del estímulo. Y finalmente, entre los factores relacionados con el propio sujeto y la estructura de su actividad cabrían mencionar: (i) la influencia de las necesidades, los intereses y las disposiciones del sujeto; y (ii) la finalidad y el objeto de la actividad.

Lillo (1993) presenta pruebas demostrativas que parecen indicar que: (1) la percepción es insensible a la estimulación sostenida y (2) que para que un estímulo sea informativo deberá ir asociado a variaciones espacio-temporales. Ello le lleva a la conclusión que “... para que la estimulación sea informativa ha de tener estructura, ha de ser no-homogénea y poseer variaciones espacio-temporales."

Cabe, no obstante, a tenor de tales estudios, cuestionarse: ¿de qué dimensión se trata aquí? ¿bastaría que un estímulo fuera asociado a la variación para que éste fuera advertido por el perceptor? ¿es válida cualquier variación? Pensemos en el simple acto de encender una cerilla: ¿Pasaría inadvertida a plena luz del día? Posiblemente si. ¿Y en una habitación oscura? Seguro que no. En este sentido es muy importante la definición de Fechner (1960: 199) del término "umbral": ". . . el punto en el que un estímulo o una diferencia entre estímulos comienza a ser perceptible o desaparece." Para activar un órgano sensorial, la teoría del umbral sensorial postula ". . . la necesidad de un nivel mínimo en la intensidad de la estimulación por debajo del cual ésta no suscita sensación alguna.” (Jáñez, 1992: 2). Además, habría dos tipos de umbrales: el absoluto y el diferencial. El umbral absoluto es el 
nivel mínimo necesario para que un determinado estímulo sea captado por el sistema sensorial. Y el umbral diferencial lo define Jáñez (1992: 3) como:

"El umbral diferencial es, pues, una magnitud física, que está asociada al estímulo y que se expresará en las mismas unidades en que se mida él. A veces hay que distinguir dos umbrales diferenciales: umbral diferencial superior (UDS) y umbral diferencial inferior (UDI); el primero es el mínimo incremento perceptible y el segundo el mínimo decremento perceptible; con frecuencia son diferentes, y entonces el umbral diferencial se define como un valor intermedio a ambos."

De todo esto, parece que podemos señalar tres conclusiones: por una parte, queda empíricamente probado el papel central que la atención desempeña en el procesamiento de la información. En segundo lugar, también queda constatada la función activadora de estímulos nuevos frente a la no-activadora de estímulos habituales o ya conocidos. Y en tercer lugar, que no existen estímulos que siempre vayan a pasar inadvertidos o estímulos que siempre vayan a atraer nuestra atención (teoría de los umbrales); esto dependerá en buena medida de dos factores fundamentales: (a) las características propias del perceptor (umbrales absolutos), y (b) las características propias del entorno en relación a las del estímulo (umbrales diferenciales).

Así pues, el emisor deberá buscar un estímulo tal que sea capaz de activar un determinado esquema referencial y así hacer mutuamente manifiesto un determinado conjunto de supuestos ${ }^{7}$. Obviamente, de lo dicho se deduce que el emisor atrae de esta manera la atención del receptor a un determinado conjunto de supuestos. Sin embargo, debemos tener en cuenta ciertos condicionantes presentes en el proceso comunicativo. Como muy bien apunta Bettinghaus (1973: 30):

"Perception of a persuasive message, however, is not a passive process. The receiver is as active in the receiving process as is the source in the transmitting process. The attitudes and beliefs of the receiver mediate the way in which messages will be received and responded to."

Es decir, aunque la función del emisor es de primordial importancia, puesto que será él el encargado de producir este estímulo, no menos importante es la función del receptor, ya que éste determinará la naturaleza de dicho estímulo. Como apunta Bettinghaus (1973: 35):

"Individuals differ in the ways in which they perceive any given stimulus. For one individual, a stimulus will be perceived and quickly assimilated into an already existing frame of reference. Another individual may not assimilate as rapidly, and the stimulus will need to be repeated several times before the receiver will build it into his frame of reference."

\section{EL CONCEPTO DE PREFERENCIA}

Tal y como señala T. Hayashi (1996), el concepto de preferencia es controvertido, en tanto en cuanto implica tres perspectivas: una es de naturaleza estructural, otra psicológica, y la tercera contextual. Mientras que la primera define el par preferente basándose en su ubicación en el discurso ${ }^{8}$, la segunda tiene en cuenta lo que el hablante realmente desea o rechaza. Finalmente, la tercera la describe Hayashi (1996: 230) de la siguiente manera:

\footnotetext{
${ }^{7}$ Así, se deriva de lo expuesto anteriormente que esta fase es de importancia singular puesto que la consecución de el/los objetivo/s marcados dependerá en gran medida de la naturaleza de este conjunto de supuestos activados.
}

${ }^{8}$ Por ejemplo, los estudios encaminados en esta línea señalan que los pares no preferidos se caracterizan por demoras, preámbulos iustificadores o incluso mitigaciones. 
"... preference is conceived of as institutionally ranked conventional action where available choices are nonequivalent . . . there is no one-to-one correlation between alternative actions and type of preference. For example, while agreement may generally constitute a preferred response to assessment, it does not in a case like an argument, where the absence of disagreement is interpreted as the failure to defend one's position."

Y será precisamente esta última postura la que aquí se va a tratar de demostrar: un determinado comportamiento no puede ser clasificado como (no)preferido de antemano, sino que habrá que tener en cuenta su contextualización para llegar a conclusiones objetivas y acertadas.

Ya Weber (1993: 3) adelantaba que: "Each utterance is understood to be indexical to the prior text and the present context. It is inmediately interpretable in terms of the interactionso-far and subsequently interpretable in terms of the interaction which follows."

Esto llevará a considerar una serie de reglas que, de una u otra forma, gobiernan toda conversación. Por motivos de espacio no me voy a detener en una explicación detallada del análisis de la conversación ${ }^{9}$, pero sí tendré en cuenta algunos aspectos que considero afectan de manera especial al estudio que aquí se aborda. En concreto, habría que detenerse en la definición de pares adyacentes. Jackson y Jacobs (1981: 81) presentan la idea principal en la cual se basa la identificación y construcción de tales pares de la siguiente manera $^{10}$ :

"Adjacency pairs ... are pairs of pragmatically connected speech acts such as QuestionAnswer, Request-Grant / Refusal, Boast-Appreciation / Derision, or Assertion-Assent / Dissent. These pairs amount to conventional solutions to the problem of how to produce a relevant next turn ${ }^{11}$."

Íntimamente ligada a esta organización de pares adyacentes está la preferencia estructural por el acuerdo. Las bases para estas preferencias estructurales quedan recogidas en la siguiente cita de Jackson y Jacobs (1981: 83):

"Structural preference refers to the fact that, of the SPPs that can appropriately combine with a particular FPP, it is usually possible to distinguish one which the FPP is designed to get (the structurally preferred SPP) and one which the FPP is designed to avoid (the structurally dispreferred SPP) ... The range of responses that lie between the preferred and dispreferred SPPs bear a general resemblance to the hedged acts ${ }^{12}$ discussed in the politeness literature."

\footnotetext{
${ }^{9}$ Existe una literatura bastante amplia en el área del análisis conversacional. Para una información más completa se puede consultar en: Atkinson y Heritage (1984), Psathas (1995), Sacks, Schegloff y Jefferson (1974) o Tsui (1994).

${ }^{10}$ Presentada por vez primera en, Sacks et alii (1974).

${ }^{11}$ Un turno quedaría definido de la siguente manera: "A turn-taking system is simply the procedural mechanism that any discursive form has for allocating the floor among individual speakers for particular units of talk" (Jackson y Jacobs, 1981: 80).

${ }^{12} \mathrm{Al}$ hablar de la mitigación, Brown y Levinson (1987: 145) explican:

"In the literature, a 'hedge' is a particle, word, or phrase that modifies the degree of membership of a predicate or noun phrase in a set; it says of that membership that it is partial, or true only in certain respects, or that it is more true and complete than perhaps might be expected".
} 
Aunque con terminología distinta, Pomerantz (1984) trata en profundidad las expresiones de acuerdo y desacuerdo. En concreto, esta autora habla de prior/second assessments $^{13}$. Las evaluaciones quedan definidas de la siguiente manera (Pomerantz, 1984: 57): "Assessments are produced as products of participation; with an assessment, a speaker claims knowledge of that which he or she is assessing." Toda evaluación puede ir seguida de otra y es en esta situación donde Pomerantz (1984: 59) habla de evaluaciones posteriores. Es decir: "Second assessments are assessments produced by recipients of prior assessments in which the referents in the seconds are the same as those in the priors."

Todo individuo, al producir una evaluación posterior, se encuentra ante la posibilidad de expresar acuerdo o desacuerdo con la evaluación previa. De esta manera, nos encontraríamos básicamente con una estructura similar a la anterior.

Esta visión de la expresión del acuerdo y el desacuerdo es compartida también por gramáticos como Leech y Svartvik (1975: 123) quienes señalan que: "Agreement and disagreement are types of affirmation and denial in which the expression of judgement or opinion rather than the assertion of fact is involved."

Siguiendo a Pomerantz, una evaluación inicial puede además estar estructurada de tal forma que invita a un tipo de acción específica sobre otra. En este caso, si la acción tomada en la evaluación posterior se corresponde con la orientación de la evaluación inicial, se hablará de una "preferred next action"14; si por el contrario se corresponde con su alternativa, se dirá que es una "dispreferred next action"15.

En este punto, Pomerantz hace una salvedad bastante importante al advertir que el acuerdo no es de forma invariable una acción siguiente preferida. Y continúa (1984: 64) señalando:

"What is the preferred next action is structured, in part, by the action performed with the initial assessment. For example, subsequent to a self-deprecation, the usual preference for an agreement is nonoperative: An agreement with a prior self-deprecation is dispreferred."

En la gran mayoría de las ocasiones, la elección entre una acción preferida y una nopreferida siempre estará sujeta a cuestiones puramente sociales. Este factor queda advertido en manuales de gramática como el de Leech y Svartvik (1975: 123) quienes advierten: "It is all the more necessary not to offend standards of politeness when the other person's judgement is in question."

Brown y Levinson (1987: 38) aseguran que la identificación de una respuesta como preferida o no-preferida depende de consideraciones tan sociales como la atención a la imagen:

"For example, taking the above list ${ }^{16}$, agreement is preferred because disagreement is an FTA; self-repair because correction by other may imply that self is misguided or incompetent;

\footnotetext{
${ }^{13}$ De ahora en adelante "evaluación previa o inicial” y "evaluación posterior".

${ }^{14}$ Levinson (1983) también hace esta distinción.

${ }^{15}$ De ahora en adelante "acción siguiente preferida" y "acción siguiente no-preferida."
}

${ }^{16}$ Se refiren a (1987: 38): "(i) agreement (vs. disagreement); (ii) repair by self (vs. repair by other of mistake or unclarity by self); (iii) acceptances (vs. rejections) or requests and offers; (iv) answers (vs. non-answers) to questions; in addition, preferences also hold across sequence types; for example, (v) offers by A (as opposed to requests by B to A); (vi) recognition by other of self on telephone (vs. self-identification) and son on." 
acceptance of offers or requests because the alternative refusals would imply lack of consideration; as might non-answers to questions. In the case of (v), the preference for an offer-acceptance sequence over a request-acceptance sequence, clearly there is less face risk in $\mathrm{A}$ 's inducing $\mathrm{B}$ to make an offer than in $\mathrm{A}$ making a request of $\mathrm{B}$, because $\mathrm{B}$ may refuse the request, but not withdraw the offer. And in the case of (vi), the preference for recognition without over self-identification on the telephone can be attributed to the deleterious positiveface implications of failure on immediate recognition (like name forgetting)."

Además, esta elección está tan íntimamente ligada a la cortesía, que Brown y Levinson (1987) incluyen entre sus estrategias orientadas a la cortesía positiva:

1. Buscar el acuerdo mediante:

- Temas seguros.
Repetición.

2. Evitar el desacuerdo mediante:

$\begin{array}{ll}\text { - } & \text { Acuerdos simbólicos. } \\ \text { - } & \text { Pseudo-acuerdos. } \\ \text { - Opiniones mitigadoras. }\end{array}$

Estas estrategias están incluidas dentro de un mecanismo que Brown y Levinson denominan la declaración de afinidades comunes: puntos de vista, opiniones, actitudes, conocimiento o empatía.

Leech y Svartvik (1975) mencionan una serie de mecanismos para expresar: un acuerdo, un desacuerdo diplomático o discreto, un acuerdo parcial o limitado, y una corroboración.

Según Pomerantz (1984), básicamente, una evaluación posterior podría ofrecer alguna de las siguientes posibilidades:

(1) Prefiriéndose el acuerdo;

(a) un acuerdo,

(b) o un desacuerdo.

(2) No-prefiriéndose el acuerdo;

(a) un desacuerdo,

(b) o un acuerdo.

Finalmente, también dentro de la oratoria, la manipulación de las expresiones de acuerdo y desacuerdo es un recurso bien conocido. Así, Zillman (1972: 159) señala:

"Since the Sophists it has been felt that, in a debate situation, it is advantageous for the speaker to get his opponent to express agreement with particular arguments advanced. Frequent agreement, it was felt, would create the impression of superior knowledge and reasoning on the part of the speaker, and lead the audience to doubt the opponent's expertise and credibility."

Este mismo autor señala que la manera más evidente de provocar una respuesta de admisión es por medio de preguntas que claramente estén solicitando el acuerdo de su oponente. Zillman (1972) denomina este tipo de preguntas "preguntas retóricas de acuerdo" 17 y la efectividad de éstas reside en que despiertan la mente del interlocutor de tal manera que le hacen más consciente de su posición. Por tanto, es mucho más efectivo que una simple afirmación por parte del orador.

${ }^{17}$ Literalmente Rhetorical agreement question. 


\section{UNA EJEMPLIFICACIÓN: LAS PREGUNTAS QUE BUSCAN EL ACUERDO}

Para poder proceder al estudio de todas aquellas preguntas que estuvieron orientadas a la búsqueda del acuerdo y el desacuerdo, lo primero fue realizar un análisis completo del corpus seleccionado. El procedimiento empleado fue el siguiente: (1) se hizo un cómputo del número total de preguntas utilizadas en cada una de las cinco sesiones ${ }^{18}$; y (2) se distinguió la sintaxis propia de cada pregunta y se estableció una diferencia entre: (a) "sintaxis interrogativa" / "sintaxis no interrogativa". Otro aspecto importante que se consideró en la clasificación de las preguntas fue la separación en: (1) preguntas producidas durante la exposición de la pregunta que el diputado interrogador había presentado anteriormente por escrito a la Mesa y (2) las realizadas durante el turno de preguntas suplementarias.

En el caso concreto de las preguntas que buscaban acuerdo o desacuerdo, el primer aspecto que se tuvo en cuenta fue que éstas no sólo se materializaban con el verbo agree, sino también mediante otras formas. El procedimiento que se utilizó para reconocer estas preguntas enmascaradas bajo un verbo que no era agree fue probar a parafrasearlas por unas que contuviesen este verbo, pero sin que por ello perdieran su sentido. Evidentemente, también se incluyó información sobre el tipo de respuesta. Éstas presentaron las siguientes formas: (a) un acuerdo o un desacuerdo implícito o explícito, o (b) simplemente una nocontestación donde el que responde no expresaba el acuerdo o el desacuerdo solicitado en la pregunta. Además, también se incluyeron una serie de declaraciones que expresaban un claro acuerdo o desacuerdo, pero sin una pregunta que invitara a ello.

Los resultados obtenidos se podrían resumir en 9 puntos ${ }^{19}$ :

1. Un $33^{\prime} 1 \%$ de las preguntas realizadas estaban orientadas a buscar el acuerdo o el desacuerdo: un $28 \%$ de ellas de forma explícita con el verbo to agree y el resto $(72 \%)$ de forma implícita con otras formas.

2. Ambas partes utilizaron, casi por igual, este tipo de preguntas: los DPGs un $35^{\prime} 1 \% \%$ (67 / 191), y los DOs un 31'4\% (72 / 229). Sin embargo, los primeros las usaron mayoritariamente cuando la pregunta era beneficiosa para el emisor y el receptor (67'2\%: $45 / 67)$, y los segundos cuando era beneficiosa para el emisor pero perjudicial para el receptor (83'3\%: $60 / 72)^{20}$.

3. En las preguntas que buscan el acuerdo o el desacuerdo de forma explícita (i.e. utilizando to agree), quienes las usan mayoritariamente son los DPGs (25/191= $\left.13^{\prime} 1 \%\right)$ en claro contraste con la Oposición $\left(14 / 229=6{ }^{\prime} 1 \%\right)$.

4. Por lo general, la respuesta elegida es la no contestación (30’2\%), pero en las preguntas formuladas explícitamente (to agree) es el acuerdo explícito (38'5\%). Estos resultados no son de extrañar, si se tiene en cuenta que, en el segundo caso, la mayoría de las preguntas fueron formuladas por los DPGs y con orientación de beneficio para el Gobierno.

5. De los 38 desacuerdos encontrados, 34 son hacia la Oposición, y 4 hacia un DPG. Y de los 59 acuerdos, 8 son hacia la Oposición y 51 hacia un DPG.

\footnotetext{
${ }^{18}$ Destinado a conocer no tanto el número como la frecuencia con la que los diputados las utilizaban.

${ }^{19}$ Se van a utilizar la siguientes abreviaturas: DPG = Diputado perteneciente al Partido del Gobierno; DMG = Diputado Miembro del Gobierno; y DO = Diputado de la Oposición.
}

${ }^{20} \mathrm{Se}$ recuerda que el receptor siempre será un representante ministerial. 
6. Otro dato curioso es que la Oposición tan sólo realizó una pregunta con orientación de beneficio para el receptor ${ }^{21}$. En el caso de los DPGs, no hay ni una ocasión en la que se emita una pregunta con orientación perjudicial para su colega.

7. Curiosamente, tan sólo hay un acuerdo explícito a una pregunta producida por la Oposición (tercera sesión: 6b), y un desacuerdo explícito a una pregunta producida por un DPG (tercera sesión: 3b(B)). La diferencia en bastante interesante:

[6.b] Mr. Fisher [Lab.]: Will the Under-Secretary acknowledge that it is a Labour authority that has provided those good educational standards despite restraints on spending by central Government?

Mr. Dunn [Con.]: I acknowledge that it is a Labour authority -I wish it were not. I remind the House that Government plans for local authorities current expenditure in 1988-89 represent an increase in cash of nearly 8 per cent. over the plans for the current year I am extremely proud of that.

[3.b] Mr. Rhodes James [Con.]: I congratulate my hon. Friend on the proposed amendments by my right hon. Friend the Secretary of State relating to higher education. [A] Does this not show the value of consultation? [B] Is it not nice to know that occasionally sanity can prevail?

Mr. Jackson [Con.]: Sanity has always prevailed. The Government listen to what is said during debates in the Standing Committee and outside, and they respond to that. We have responded with amendments to other parts of the Bill, and we are so responding in respect of the clauses that will be debated this afternoon.

Como puede observarse en el caso de la pregunta presentada por la Oposición, ese "I wish it were not" deja bien claro el deseo de no querer expresar acuerdos con la Oposición. Por el contrario, en el excepcional desacuerdo explícito con un colega, el representante ministerial no hizo ninguna aclaración puesto que no quería señalar este desacuerdo.

8. Además se encontraron 14 expresiones de acuerdos y desacuerdos explícitos sin haber sido solicitados. Con este comportamiento, quedan bien claras las preferencias de cada bando.

9. El 97'1\% de las preguntas que buscan acuerdo o desacuerdo son preguntas retóricas.

Si se repasan una vez más las estrategias de cortesía citadas por Brown y Levinson (1987), hay tres -todas ellas de cortesía positiva- que adquieren especial relevancia en este apartado:

"5. Seek agreement: safe topics, repetition"

"6. Avoid disagreement: token agreement, pseudo-agreement, white lies, hedging opinions"

Tomemos en consideración la primera de estas estrategias y recordemos algunos de los datos: la Oposición tan sólo realizó una pregunta con orientación de beneficio y el 83'3\% (60 / 72) de las preguntas tenían orientación perjudicial, y por tanto, como era de esperar, el $533 \%$ (32/60) de ellas (i.e. de las realizadas con orientación perjudicial) recibió una

\footnotetext{
${ }^{21}$ Pregunta que se analizará más adelante y que, como se podrá comprobar, en realidad, no era tan inocente. En un sentido estricto, no debería incluirse en este apartado (i.e. de beneficio) pero dada la formulación especial de esta pregunta, decidí incluiria como "con orientación de beneficio para el receptor".
} 
respuesta de desacuerdo y el 45\% (27/60) una no contestación ${ }^{22}$. Tomemos la siguiente cita de la cuarta sesión, que dejará bastante claro el tipo de comportamiento preferido:

[1.c] Mr. Straw [Lab.]: Has the Secretary of State explained to the Prime Minister that her desire for crude pass-fail tests in the national curriculum would not only lower educational standards but would require a vast army of external examiners and inviligators, which would cost a great deal more than Professor Black's proposals? I assure the Secretary of State that so long as he fights hard against the Prime Minister and the other forces of darkness in this area, he has our full support.

Mr. Baker [Con.]. I do not think that I want that sort of support. As the hon. Gentleman knows, debates on such matters are vigorous and robust, and now sometimes public. However, all decisions taken on such matters are collective decisions.

I am glad that in Committee the Labour party did not vote against any of the clauses on the national curriculum or on financial delegation, and it virtually approved open enrolment. The fact is that the hon. Gentleman did his duty, but basically he knows that we are right.

Obviamente, la Oposición: (1) busca el desacuerdo y, por eso, (2) utiliza tema u orientaciones que casi seguro le llevan a ello. Y ahora nos podríamos preguntar ¿está la Oposición comportándose estratégicamente? o ¿ son estrategias de cortesía? o ¿sería un comportamiento descortés? Habrá que esperar a la aplicación de un enfoque integrador social-cognitivo para poder contestar a estas preguntas.

En el caso de los DPGs, las cifras cambian: no realizan ni una pregunta con orientación perjudicial y la mayoría de las preguntas tenían orientación de beneficio $(67 ' 2 \%=45$ / 67), y por tanto, como era de esperar, el $9717 \%$ de ellas (44/45) recibe una respuesta de acuerdo. Obviamente, los DPGs: (1) buscan el acuerdo y para ello (2) utilizan temas u orientaciones que se lo van a proporcionar. Y ahora nos preguntaríamos de nuevo: ¿están los miembros del Gobierno comportándose estratégicamente? o ¿son estrategias de cortesía? o ¿serían estrategias de cortesía positiva? Pero una vez más habrá que esperar a la aplicación de un enfoque integrador social-cognitivo para poder contestar a estas preguntas.

Revisemos ahora la segunda de las estrategias arriba mencionadas (i.e. "Avoid disagreement: token agreement, pseudo-agreement, white lies, hedging opinions"). Si tenemos en cuenta los datos que reflejan el comportamiento de la Oposición, ¿podríamos decir que están buscando el acuerdo? Sería algo irónico. Entonces, ¿cómo interpretar su comportamiento?. En cuanto a los miembros del Gobierno, ¿podríamos decir que evitan el desacuerdo? En términos generales podríamos decir que sí desde los dos ángulos. Es decir, desde el del DPG como individuo que pregunta (que ya se vió antes), y desde el del DMG que contesta. Inspeccionemos este último caso. Debido a la mayoritaria orientación perjudicial de las preguntas presentadas desde la Oposición, el representante ministerial se ve obligado a expresar el desacuerdo (47'2\%: 34 / 72) o a no contestar (41'7\%: $30 / 72)$. Sin embargo, en el 79'4\% (27 / 34) de las ocasiones lo hace implícitamente. Es decir, en cierto modo evita una expresión explícita del desacuerdo. Además, el porcentaje se eleva cuando a quien tiene que expresar el desacuerdo es a un colega del partido del Gobierno: en tan sólo una ocasión expresa un desacuerdo de manera explícita. Estas tendencias, nuevamente, 
plantean preguntas del tipo: ¿están comportándose estratégicamente tanto la Oposición como los representantes ministeriales? ¿son estrategias de cortesía? ¿son los DGPs más corteses que los DOs? ¿están los representantes ministeriales utilizando estrategias de cortesía positiva con la Oposición al evitar los desacuerdos explícitos? ¿son más corteses los representantes ministeriales con sus colegas que con la Oposición?

En definitiva, no sólo son muchas las preguntas que plantea la aplicación de un modelo únicamente social, sino también difíciles de responder. Tendremos que esperar a una reinterpretación teniendo en cuenta factores cognitivos para poder dar respuestas a estas preguntas.

Tal y como se señaló anteriormente, la expresión de acuerdo o desacuerdo no está solamente ligada a la manifestación de un comportamiento más o menos cortés ${ }^{23}$, sino que su manipulación es un recurso bien conocido por todo buen orador (Zillman, 1972: 159). De esta manera, una expresión de acuerdo ante una pregunta de un adversario político será evitada a toda costa. Por tanto, ¿sería lógico pensar que la expresión de acuerdo o desacuerdo fuera capaz de activar en el emisor el esquema referencial sobre su relación social con el receptor y le hiciera pensar que este último le tiene en más baja/alta estima social de lo que él suponía? Tal y como se recordará, Luria (1987) señalaba entre los factores que determinaban el volumen de la atención de un individuo aquéllos relacionados con el propio sujeto y la estructura de su actividad. Éstos eran: (i) la influencia de las necesidades, los intereses y las disposiciones del sujeto; y (ii) la finalidad y el objeto de la actividad. Teniendo en cuenta todos estos factores y las características específicas del escenario en el que nos encontramos, los aspectos puramente sociales pasan a un segundo plano en la atención del individuo. Toda su atención se centraría en un objetivo tan inmediato como necesario: influir en la opinión del/de los receptor/es para ganar la batalla política. Tal y como explica Franklin (1970: 71):

"In fact there is hardly a single feature in the daily life of the average M.P. which is not concerned in some way with the communication of opinion. . And most of this information is intended to influence opinion."

Como se pudo comprobar en las cifras anteriores, el 97'1\% de las preguntas eran, además, retóricas. Este dato corrobora la posición de Zillman (1972) que señalaba que la mejor manera de provocar una respuesta de admisión es por medio de preguntas que claramente estén solicitando el acuerdo de su oponente por medio de las denominadas "preguntas retóricas de acuerdo". Un ejemplo de este tipo de preguntas sería: "Prices have gone up, haven't they?" donde se espera una respuesta como "Yes, they have" y se excluye otra del tipo "No, they haven't". Estas preguntas están destinadas a activar el esquema referencial deseado por su interlocutor y le haría más consciente de su posición hacia un determinado asunto. De esta manera, este comportamiento le haría manifiesto (o más manifiesto) a su receptor un conjunto $\{\mathrm{I}\}$ de supuestos sobre la postura del emisor ante un asunto determinado. Tal y como Zillman (1972: 161) indicaba:

$" .$. the assumed covert agreement response elicited by a rhetorical agreement question ... raises the individual level of awareness ${ }^{24}$. It makes him cognizant of his position on a

\footnotetext{
${ }^{23}$ Finalidad que además no quedó muy clara anteriormente dadas las dudas a las que nos conducían las conclusiones.

${ }^{24}$ Las negrillas son mías.
} 
particular issue, and it may activate issue-related cognitions to consolidate and bolster his evaluations, thereby facilitating his involvement with the issue, and possibly producing some self-commitment."

Además, tal y como Roiz (1994) señala, todos los procedimientos persuasivos van orientados a: (1) disminuir las resistencias psicológicas de los receptores; (2) verificar la correcta transmisión del mensaje; y (3) captar la atención del auditorio. Así, por medio de estas preguntas que buscan acuerdo o desacuerdo, la atención del receptor se centra en un aspecto específico. Asimismo, dado el carácter retórico de la gran mayoría de estas preguntas, la idea es presentada de forma directa y simplificada ${ }^{25}$, como corresponde a una fuerte aserción. De esta manera, se cumple una de las seis reglas generales de la persuasión $^{26}$ : la simplificación ${ }^{27}$. Roiz (1994: 57) aclara:

“. . la simplificación intenta, cada vez que se elabora un mensaje persuasivo, concentrarse en un objetivo principal ... se pone énfasis en un aspecto muy relevante y significativo para el receptor ... La técnica de concentración de objetivos."

Como se recordará, además, en el caso de las preguntas presentadas desde la Oposición, el $833 \%(60 / 72)$ de ellas tuvieron una orientación perjudicial para el receptor. Esto provocaría una mayor reacción en éste, que tratará a toda costa de desmentir algo así. Uno de estos casos se puede observar en la siguiente cita tomada de la tercera sesión:

[9.a] Mr. Maxton [Lab.]: [A] Is the Minister aware that despite his answer, there are many young outstanding scientists in Britain who are deterred from undertaking postgraduate research or who go abroad to do that research because of the poor career prospects in Britain? [B] Does he agree with Sir David Philips, chairman of the Advisory Board for the Research Councils, that we are in great danger of falling behind our foreign competitors in terms of industrial development because of the Government's failure properly to invest in civil research? [C] Will the Government ever understand the close connection between Government-backed investment and industrial development?

Mr. Jackson [Con.]. I have to point out to the hon. Gentleman that the numbers of postgraduates in science have increased by one third since 1979. As for his observations about Government expenditure on civil research and development, an examination of the proportion of the national product invested in civil research and development by Governments makes it clear that we spend more than the United States and Japan.

En la pregunta 9.a(B), Mr. Maxton está claramente solicitando que Mr. Jackson exprese su acuerdo con una afirmación que no hace sino acusar al Gobierno de llevar a cabo malas gestiones. Ante esta pregunta, Mr. Jackson expresa su desacuerdo de manera implícita. El hecho de haber elegido este tipo de respuesta está directamente relacionado con el patrón de la pregunta. Si Mr. Jackson hubiera contestado algo así como "I disagree with him (i.e. Sir

\footnotetext{
${ }^{25}$ En el sentido de que una pregunta retórica equivale a una fuerte aserción, clara y evidente.
}

${ }^{26}$ Las seis reglas señaladas por Roiz (1994) eran: (1) la explotación de los sentimientos; (2) la simplificación; (3) la exageración y la desvirtuación de la información; (4) la repetición de temas e ideas de forma orquestada; (5) la explotación del contagio psíquico; y (6) el apoyo en las actitudes preexistentes.

${ }^{27}$ La simplificación también está íntimamente ligada a una lev gestáltica: "la lev de la simnlicidad”. 
David Philips)", esto implicaría que Mr. Jackon estaría reconociendo la existencia del problema que está presentando Sir David Philips. Según la lógica presuposicional, si un individuo dice "No estoy de acuerdo con lo que María ha dicho (i.e. que Luis ha ido a Barcelona)", ésto presupone: (a) que existe una persona que se llama María; (b) que María ha dicho algo; (c) que existe una persona llamada Luis; y (d) que Luis ha viajado a Barcelona $^{28}$. Ante este tipo de pregunta, Mr. Jackson decide responder ofreciendo argumentos que debilitan la propuesta de Sir David Philips. De esta manera no se le podría acusar en ningún momento de estar admitiendo absolutamente nada.

En el caso de los DPGs, el 67'2\% (45 / 67) es claramente beneficiosa para el receptor y análogamente, también provoca una fuerte reacción en el receptor que se apresurará en consolidar esa aseveración. El siguiente ejemplo (primera sesión) muestra esta situación:

[11.a] Mr. Evans [Con.]: The representations are encouraging. Does my right hon. Friend agree that when the Bill becomes law the inquiries will increase substantially and, furthermore, that pupils will at last be educated according to the wishes of their parents?

Mr. Baker [Con.]: I agree with my hon. Friend. I think that this will prove to be a very popular measure and will implement the very phrase in his question, which he drew from the Education Act 1944.

Como puede observarse, salta a la vista que las diferencias con respecto a los casos anteriores son evidentes. En 11.a, Mr. Evans le está pidiendo al ministro Mr. Baker que exprese su acuerdo con algo que no es ni más ni menos que una propaganda política del Gobierno. Como repuesta, no sólo expresa un acuerdo categórico, sino que aumenta la propaganda reforzando la aseveración con informaciones positivas suplementarias.

Sin embargo, si un $672 \%$ de las preguntas buscando acuerdo o desacuerdo formuladas por los DPGs tienen orientación de beneficio, eso quiere decir que hay un 32'8\% restante con orientación "no perjudicial"29. La explicación radica, una vez más, en la defensa de los intereses que cada representante político del Gobierno debe a su circunscripción. A veces, estos intereses no coinciden plenamente con los del Gobierno y la pregunta no puede ser presentada como beneficiosa y lo es como "no perjudicial". Un ejemplo de pregunta "no perjudicial" es (segunda sesión):

[6.e] Mr. Madel [Con.]: [A] Is not one of the causes for a school to consider opting out the proposal by a local education authority to close a popular school whose numbers have been artificially restricted and which has been deliberately underfunded by that authority? Although my right hon. Friend cannot comment on such proposals until they reach his desk, [B] can he confirm that he is naturally sympathetic to such schools?

Mr. Baker [Con.]. I know what is behind my hon. Friend's question, and I certainly cannot comment upon it. However, if popular schools have been underfunded, other measures in the Bill will improve that as well. It is absurd to have empty desks in popular schools, and our open enrolment clauses will put paid to that practice. Obviously many different types of school in many different circumstances will want to consider grant-maintained status, and my hon. Friend may well have identified one such circumstance.

\footnotetext{
${ }^{28}$ Yo no podría estar de acuerdo con María porque, en realidad, a Luís le llevaron a Barcelona.

${ }^{29}$ Puesto que no se encontró ninguna con orientación "perjudicial".
} 
La pregunta 6e(B) fue clasificada como "no-perjudicial" y recibió una "no contestación" ${ }^{\prime 30}$. Mr. Madel, diputado conservador por South West Bedforshire, está claramente defendiendo los intereses de su circunscripción. En concreto, está pidiendo algo así como una "consideración especial". Esto se convierte en una pregunta bastante peligrosa porque: (1) si Mr. Baker da su asentimiento, está demostrando un favoritismo especial por los diputados de su partido, pero (2) si no lo da, no sólo defraudará a sus seguidores conservadores, sino que dará la razón a Mr. Madel en lo que fue la primera parte de su intervención cuando dijo "one of the causes for a school to consider opting out [is] the proposal by a local education authority to close a popular school whose numbers have been artificially restricted and which has been deliberately underfunded by that authority", y ésta es una acusación muy peligrosa. Sobre todo si se tiene en cuenta que, a fecha de 19 de enero de $1988^{31}$, la composición de la $\mathrm{AEL}^{32}$ de Bedforshire era: Laboristas: 29; Conservadores: 30; Liberales/Alianza SDP: 11; y Liberales: $3^{33}$. Ante esta difícil situación, Mr. Baker, aunque responde a la pregunta, decide no contestarla.

Una vez ha quedado claro que estas preguntas son realmente capaces de llamar la atención del individuo y hacerle más manifiesto su postura sobre un asunto determinado, ahora nos podríamos preguntar iy ha sido capaz de provocar el cambio deseado? Para poder saberlo, lo primero que habría que conocer sería la naturaleza de los esquemas referenciales del receptor con relación a la idea o postura que se presenta. Si los esquemas están fuertemente consolidados y la idea que se presenta entra en contradicción, será muy difícil que se produzca un cambio. La modificación deseada será más probable cuanto menos extenso y completo sea el esquema referencial que se pretende alterar.

\section{a) Preguntas producidas por la Oposición}

En primer lugar, veamos cuál sería la trayectoria en el caso de aquellas preguntas producidas por la Oposición.

Si se tienen en cuenta los factores dificultan/facilitan un cambio en los esquemas referenciales del receptor y las características del receptor de las preguntas presentadas por la Oposición, las posibilidades no podían ser más escasas. Pero ahora nos preguntaríamos ¿y esta Oposición sería tan poco astuta como para utilizar ( $i y$ con una frecuencia de un 31 '4\% (72/229)!) una estrategia que casi con seguridad le va a conducir al fracaso? Para conocer la respuesta a esta pregunta, revisemos un dato: las preguntas presentadas por la Oposición que buscaban acuerdo o desacuerdo recibieron como respuesta un desacuerdo en un 47'2\% (34 / 72) de los casos, y una no contestación en un 41'7\% (30 / 72). Según clasificaciones puramente sociales ${ }^{34}$, serían respuestas aparentemente "no-preferidas". Sin

${ }^{30}$ De hecho, el 50\% (11/22) de las preguntas formuladas por DPGs con orientación "no perjudicial" recibieron por respuesta una "no contestación".

${ }^{31}$ Que es cuando tuvo lugar esta segunda sesión de Preguntas Orales.

${ }^{32} \mathrm{O}$ "Autoridades Educativas Locales" (Local Education Authorities (LEA $)$ ).

${ }^{33}$ Esta información ha sido proporcionada por Mr. C. Pond (HOC Library) en comunicación personal.

${ }^{34}$ Como se recordará, Brown y Levinson (1987:38) sostenían: "For example, taking the above list, agreement is preferred because disagreement is a FTA; self-repair because correction by other may imply that self is misguided or incompetent; acceptance of offers or requests because the alternative refusals would imply lack of consideration: as might non-answers to auestions." 
embargo, tal y como apuntaba Pomerantz (1984:64), para saber si realmente es una segunda parte (no)preferida del par, habría que estudiar la orientación de la primera parte del par o evaluación previa.

Si se tiene en cuenta que el $8313 \%(60 / 72)$ de las preguntas presentadas por la Oposición tiene una orientación perjudicial para el receptor, es evidente que lo que se buscaba y se esperaba del receptor era un desacuerdo, y por tanto, este desacuerdo era la segunda parte preferida del par. Tal y como ya se anticipó, existe una única pregunta en la que la orientación era de beneficio. Pero, como ya se advirtió en su momento, no se trata de una pregunta "inocente" (primera sesión):

[8.d] Mr. Andrew F. Bennett [Lab.]: [A] Does the Minister agree that one of the best parts of the White Paper was the Government's commitment to greater access to education for adults? [B] Will he say how much money the Government will put up to make it easier for adults to gain access to education? [C] How will he co-ordinate the provision for adults returning to education between $\mathrm{FE}$ and $\mathrm{HE}$ colleges, polytechnics and universities? [D] Do we not need a national co-ordinating body to allocate resources and courses for adults returning to education, $[\mathrm{E}]$ or is it the Government's intention to apply competition so that these institutions compete for students and resources?

Mr. Jackson [Con.]: The Government's commitment to this matter is plain. There has been an increase of 160,000 students in the system since 1979, an 8 per cent. increase in UGC funding- following a 10.2 increase last year- and a 9 per cent. increase in funding for polytechnics and colleges this year. That is ample evidence of the Government's commitment to achieving their target.

En la pregunta 8d(A) Mr. Andrew F. Bennett está claramente (1) solicitando una expresión de acuerdo de Mr. Jackson, y (2) emitiendo una fuerte aserción: "that one of the best parts of the White Paper was the Government's commitment to greater access to education for adults". En un principio, esto parecería una pregunta inocente con clara orientación de beneficio para su receptor, puesto que los que está poniendo de relieve uno de logros del Gobierno ${ }^{35}$. Sin embargo, este turno se compone de más preguntas $(8 \mathrm{~d}(\mathrm{~B}, \mathrm{C}, \mathrm{D}, \mathrm{E}))$ y éstas se centran en un grave problema que estaba sacudiendo al sistema educativo a partir de los 16 años $^{36}$. En resumen, la pregunta de Mr. Andrew F. Bennett está poniendo sobre la mesa uno de los problemas más criticados de esta Reforma Educativa: la competitividad en el sistema educativo ${ }^{37}$. De esta manera, la primera pregunta (8d(A)) se podría denominar una pregunta "cebo", en tanto en cuanto, si se admite lo que en ella se está afirmando, no se podrán negar las peticiones que se hacen a continuación. La respuesta de Mr. Jackson expresa un claro acuerdo con la primera pregunta profundizando en ella con cifras y argumentos pero sin mencionar las otras cuatro.

\footnotetext{
${ }^{35}$ De hecho, por este motivo esta pregunta ha sido incluida entre aquellas "con orientación beneficiosa para emisor y receptor".

${ }^{36}$ Ya sea en los denominados Further Education Colleges, High Education Colleges, en Polytechnics, o en Universities.

${ }^{37}$ La crítica más ferviente a esta Reforma se podría resumir en una frase: la capitalización del sistema educativo como si de una empresa se tratara.
} 
Por tanto, está claro que si la única pregunta con orientación de beneficio tiene una función "cebo" y el 83'3\% (60/72) de las preguntas tiene una orientación perjudicial para el receptor $^{38}$, es evidente que lo que se buscaba y se esperaba del receptor era un desacuerdo. Así pues, si se tiene en cuenta (1) la poca eficacia de esta estrategia dadas las características del receptor, y (2) la voluntad constatada de no buscar su acuerdo, cabe preguntarse ¿qué utilidad tiene esta estrategia?

Es obvio que una finalidad con doble vertiente. Según Wyer (1977), parece ser que el individuo discute menos si la información no contradice su propia información: "The ability to do so [to counterargue] may depend upon two things; the availability of information to use in refuting the arguments presented in communication, and the practice one has had in counterarguing." (Wyer, 1977:271). Ante esta tendencia, parece evidente que lo que está haciendo es (a) provocar una discusión y, con ello, (b) poner a prueba públicamente la calidad de su adversario. Además, según señala Wyer (1977), una técnica utilizada en la persuasión es el ataque a la fuente de la información, por tanto, nada mejor que desacreditarla y poner en tela de juicio su competencia. Finalmente, para suscitar esta discusión nada mejor que hacerlo mediante una fuerte aserción perjudicial para el receptor en la forma de una pregunta retórica y preferentemente en forma negativa. De ahí que el $674 \%$ (29/43) de las preguntas negativas realizadas tengan como emisor a un diputado de la Oposición.

Por tanto, las conclusiones son tan evidentes como obvias: de cara al receptor directo del intercambio (i.e. el representante ministerial del Gobierno), éste no sería un comportamiento estratégicamente persuasivo. Todo indica que no es a este receptor al que se pretende persuadir, sino que esta finalidad iría más bien dirigida a la audiencia ${ }^{39}$. Así, estas preguntas intentarían provocar un cambio de opinión en la audiencia con una doble táctica: por una parte, le haría más consciente de su postura ante un determinado asunto por medio de este tipo de pregunta ${ }^{40}$, a la vez que presenta la del contrincante de manera desfavorable gracias al carácter retórico de las preguntas; y por otra, desacreditaría al contrincante al ponerle a prueba en sus habilidades para contra-argumentar.

\section{b) Preguntas producidas por diputados del partido del Gobierno}

En cuanto a las preguntas producidas por diputados del partido del Gobierno, el primer factor que llama la atención -a diferencia de lo que ocurría con las expuestas por la Oposición- era que el 76'1\% (51/67) obtiene un acuerdo por respuesta y tan sólo se encuentran 4 desacuerdos ${ }^{41}$. Pero no podía ser de otra manera, puesto que un 67 '2\% (45/

\footnotetext{
${ }^{38}$ Aunque existe un 11 '1\% (8/72) con la orientación "no-perjudicial", éstas no tenían como función buscar el acuerdo, puesto que tenían como tema la presentación de problemas y preocupaciones existentes.
}

${ }^{39}$ La audiencia está compuesta por: (1) el resto de la comunidad parlamentaria; (2) los periodistas; (3) una audiencia masiva integrada por todo el país gracias a la radio y la televisión; y (4) una audiencia más reducida formada por los electores de su circunscripción. Tal y como señala Pérez de Ayala (1996), es importante insistir en una idea: los parlamentarios hablan pensando en su audiencia y no sólo en su interlocutor.

\footnotetext{
${ }^{40}$ Ya quedó anteriormente constatada la gran capacidad que este tipo de preguntas ofrece para llamar la atención de un individuo.
}

${ }^{41}$ Todos ellos explícitos, menos uno que ya se trató anteriormente (3b(B) en la tercera sesión):

[3.b] Mr. Rhodes James [Con.]: I congratulate my hon. Friend on the proposed amendments by my right hon. Friend the Secretary of State relating to higher education. $[A]$ Does this not show the value of consultation? $[B]$ Is 
67) de las preguntas que realizaron tenían orientación de beneficio y un 32'8\% (22 / 67) de no perjuicio. Por tanto, también a diferencia de lo que se observó anteriormente, el segundo par preferido del turno en este caso sí sería el acuerdo. Y en este punto cabría preguntarse: ¿tendría realmente el emisor intención de cambiar la postura de $\mathrm{B}$ y, a la vez, estar realizando una fuerte aserción -puesto que son mayoritariamente retóricas- enalteciendo sus actuaciones? Como se recordará, cuando el esquema referencial del individuo era extenso y relativamente completo, una idea que no fuera contraria serviría para reforzarlo (Bettinghaus, 1973:32-3). Por tanto, los efectos de unas evaluaciones positivas sobre la Reforma realizados a los representantes ministeriales (que fueron quienes la propusieron) servirán para reforzar sus esquemas, pero nunca para cambiarlos. Al igual que hicimos antes, ahora nos tendríamos que preguntar por la naturaleza misma de este comportamiento: ¿se trata de un comportamiento estratégicamente persuasivo sin éxito porque no lograron el cambio? Ya hemos visto que sería absurdo pretender provocar algún cambio en sus colegas del Gobierno con ese comportamiento, pero ¿y en aquellos individuos cuyos esquemas mentales fueran reducidos e incompletos? Una nueva información que sea contraria a tal esquema servirá para aumentar la entropía o el grado de incertidumbre del receptor. Aunque esta nueva información no implique la desaparición de tal esquema, sin embargo, nunca será utilizada como referente a la hora de tomar futuras decisiones. Y una nueva información que no sea contraria a tal esquema servirá para disminuir la entropía o incertidumbre del receptor. De esta forma, esta nueva información ha servido para completar el esquema referencial y, por tanto, tomarlo en cuenta como referente a la hora de tomar futuras decisiones.

Por tanto, aunque con medios diferentes y por razones distintas, llegamos a la misma conclusión que en el caso anterior (i.e. el comportamiento de la Oposición): que los fines persuasivos de este comportamiento no van orientados a su receptor inmediato sino a la audiencia; aunque cabría mencionar el sector de la audiencia compuesto por los diputados de la Oposición, si éstos tienen -que es lo más lógico pensar- un esquema referencial extenso y relativamente completo, una nueva información contraria a tal esquema apenas será capaz de producir cambios apreciables en el comportamiento. De hecho, sería como si ese material no hubiera sido percibido (Bettinghaus, 1973:32-3). Además, por diversos motivos mencionados anteriormente, como la fiabilidad de la fuente, la influencia de los grupos de referencia, etc., es bastante improbable que lograra algún cambio y por tanto finalizara como una estrategia sin éxito. Sin embargo, en ese sector de la audiencia cuyos esquemas no estuvieran muy definidos, sí existirían bastantes posibilidades de concluir con éxito. Este grupo, al oír esta serie de preguntas orientadas a buscar el acuerdo, lo primero que haría sería centrar su atención en su propia posición sobre ese asunto. Si ésta, como se ha indicado, no estaba muy definida, al oír en primer lugar una evaluación positiva sobre ella en la forma de una fuerte aseveración y en segundo lugar la expresión del acuerdo por parte de otra persona, es muy probable que se produjera un cambio a favor del individuo persuasor.

it not nice to know that occasionally sanity can prevail? Mr. Jackson: Sanity has always prevailed. The Government listen to what is said during debates in the Standing Committee and outside, and they respond to that. We have responded with amendments to other parts of the Bill, and we are so responding in respect of the clauses that will be debated this afternoon.. 


\section{c) Conclusión}

Como consecuencia de esta doble interpretación de los resultados obtenidos, se demostró que una determinada forma lingüística no va siempre unida a una función específica. Tal y como se advertía en la psicología de la percepción, la existencia de los denominados umbrales absolutos y específicos hacían que un mismo estímulo pudiera pasar inadvertido o llamara la atención dependiendo de las características del perceptor y las del entorno. Y eso mismo es lo que aquí se ha podido comprobar en el terreno lingüístico: la función puramente social atribuida de manera indisoluble a determinadas formas lingüísticas pasó a formar un segundo plano en determinadas situaciones donde el individuo poseía otros anhelos y necesidades más inmediatas.

En conclusión, no he pretendido invalidar la utilidad de las denominadas estrategias de cortesía presentadas por Brown y Levinson (1986), ni separarlas terminantemente de las estrategias de persuasión. De hecho, aquí se han ido utilizando tanto factores sociales como cognitivos, porque ambos son aspectos complementarios de una realidad compleja que es el ser humano. Además, habría incurrido en el mismo error que estaba rechazando: la previa asignación de unas funciones estratégicas determinadas a una lista de formas lingüísticas. En suma, se pueden determinar tres factores esenciales en la función estratégica de cualquier comportamiento lingüístico que son imprescindibles para un análisis completo y satisfactorio de la comunicación humana: (1) las intenciones del emisor, (2) las características de su/s receptor/es, y (3) la singularidad de su entorno de emisión. Prescindir de uno de ellos supone dejar sin explicación hechos fundamentales de la comunicación.

\section{BIBLIOGRAFÍA}

R. C. ANDERSON, R.J. SPIRO y W.E. MONTAGUE (eds), Schooling and the Acquisition of Knowledge (New Jersey 1977).

J. M. ATKINSON, y J. HERITAGE (eds.), Structures of Social Action: Studies in Conversation Analysis (Cambridge 1984).

R. BAUMAN y J. SHERZER (eds.), Explorations in the Ethnography of Speaking (Cambridge 1974).

D.G. BOBROW y A.M. COLLINS (eds.), Representation and Understanding (New York 1975).

P. BROWN y S. C. LEVINSON, Politeness: Some Universals in Language Use (Cambridge 1987).

W. N. DEMBER y J.S. WARM, Psicología de la Percepción (Madrid 1990). [Título original: Psychology of Perception, 1979, $2^{\mathrm{a}}$ edición (1 ${ }^{\mathrm{a}}$ : 1960). Traducido por Celia González]

M. A. ECHEVERRÍA, Creatividad y Comunicación. Una Mecánica Operativa para la Creación de Ideas de Transmisión en los Procesos de Comunicación Persuasiva (Madrid 1995).

M. V. ESCANDELL VIDAL, Introducción a la Pragmática (Barcelona 1993).

"Towards a Cognitive Approach to Politeness", Journal of Pragmatics 18: 3-4 (1996) 629-650.

G. T. FECHNER, Elemente der Psychophysik (Leipzig 1960).

"Towards ethnographies of communication: The analysis of communicative events", American Anthropoligist 66 (1964) 1-34. 
“Ways of Speaking” en R. Bauman y J. Sherzer (Cambridge 1974) 433-451.

R. HARRIS y G. WOLF, Integrational Linguistics (London 1998).

T. HAYASHI, "Politeness in conflict management: A conversation analysis of dispreferred message from a cognitive perspective", Journal of Pragmatics 25 (1996) 227-255.

D. HYMES, “Ways of Speaking” en R. Bauman y J. Sherzer (eds.) (Cambridge 1974) 433451.

S. JACKSON, y S. JACOBS, "The Collaborative Production of Proposals in Conversational Argument and Persuasion: A Study of Disagreement Regulation", Journal of the American Forensic Association 18:2 (1981) 77-90.

L. JÁÑEZ ESCALADA, "Psicofísica” en J. Mayor y J. L. Pinillos (ed.) (Madrid 1992) 144.

G. LEECH y J. SVARTVIK, A Communicative Grammar of English (London 1975).

S. C. LEVINSON, Pragmatics (Cambridge 1983).

"Minimization and Conversational Inference" en Verschueren y M. Bertuccelli-Papi (Amsterdam 1987) 61-129.

J. LILLO JOVER, Psicología de la Percepción (Madrid 1993).

A. R. LURIA, Atención y Memoria (Barcelona 1987). [Título original: Vnimanie y Pamiat, (Moscú 1975). Traducido por Pedro Mateo Merino.]

J. MAYOR y J. L. PINILLOS (eds.), Tratado de Psicología General 3. Atención y Percepción (Madrid 1992a).

---- (eds.), Tratado de Psicología General 2. Memoria y Representación (Madrid 1992b).

M. MINSKY “A Framework for Representing Knowledge” en P.H. Winston (ed.) (New York 1975) 211-277.

The Society of Mind (New York 1986).

S. PÉREZ DE AYALA BECERRIL, "Question Time: Cortesía Lingüística en la Cámara de los Comunes". Tesis doctoral presentada en la Universidad Complutense de Madrid (Madrid 1996).

A. POMERANTZ, "Agreeing and Disagreeing with Assessments: Some Features of Preferred / Dispreferred Turn Shapes” en J. M. Atkinson y J. Heritage, (Cambridge 1984) 57-101.

G. PSATHAS, Conversation Analysis: The Study of Talk-in-Interaction (California 1995).

La Relevancia (Madrid 1994).

I. ROCK, La Percepción (Barcelona 1985).

M. ROIZ, Técnicas Modernas de Persuasión (Madrid 1994).

D. E. RUMELHART, "Notes on a Schema for Stories" en D.G. Bobrow y A.M. Collins (eds.) (New York 1975) 211-236.

A. SANFORD y S. GARROT, Understanding Written Language: Exploration in Comprehension beyond the Sentence (Chichester 1981).

H. SACKS, E. A. Schegloff y G. Jefferson "A Simplest Systematics for the Organization of Turn-Taking for Conversation”, Language 50:4 (1974) 696-735.

R. SCHANK y R. ABELSON, Scripts, Plans, Goals and Understanding. An Inquiry into Human Knowledge Structures (Hillsdale 1977).

D. SPERBER y D. WILSON, Relevance: Communication and Cognition (Oxford 1986). Relevance: Communication and Cognition (Oxford 1995).

A. B. M. TSUI, English Conversation (Oxford 1994). 
J. VERSCHUEREN y M. BERTUCCELLI-PAPI (eds) The Pragmatic Perspective (Amsterdam 1987).

E. G. WEBER, Varieties of Questions in English Conversation (Amsterdam / Philadelphia 1993).

J. WILSON, Politically Speaking: The Pragmatic Analysis of Political Language (Oxford 1990).

"Pursuing a Response" en J. M. Atkinson y J. Heritage (Cambridge 1984) 152-163.

P.H. WINSTON (ed.) The Psychology of Computer Vision (New York 1975).

R. S. WYER, "Attitudes, Beliefs, and Information Acquisition" en R. C. Anderson et alii. (eds) (New Jersey 1977) 259-288.

D. ZILLMAN, "Rhetorical Elicitation of Agreement in Persuasion", Journal of Personality and Social Psychology 21:2 (1972) 159-165. 
